\title{
The regulation of hematopoietic stem cell populations
}

\section{[version 1; peer review: 2 approved]}

\author{
Hector Mayani
}

Hematopoietic Stem Cells Laboratory, Oncology Research Unit, IMSS National Medical Center, Mexico City, Mexico

\author{
V1 First published: 28 Jun 2016, 5(F1000 Faculty Rev):1524 \\ https://doi.org/10.12688/f1000research.8532.1 \\ Latest published: 28 Jun 2016, 5(F1000 Faculty Rev):1524 \\ https://doi.org/10.12688/f1000research.8532.1
}

\section{Abstract}

Evidence presented over the last few years indicates that the hematopoietic stem cell (HSC) compartment comprises not just one but a number of different cell populations. Based on HSCs' proliferation and engraftment potential, it has been suggested that there are two classes of HSC, with long- and short-term engraftment potential. HSC heterogeneity seems to involve differentiation capacities as well, since it has been shown that some HSC clones are able to give rise to both myeloid and lymphoid progeny, whereas others are lymphoid deficient. It has been recognized that HSC function depends on intrinsic cell regulators, which are modulated by external signals. Among the former, we can include transcription factors and non-coding RNAs as well as epigenetic modifiers. Among the latter, cytokines and extracellular matrix molecules have been implicated. Understanding the elements and mechanisms that regulate HSC populations is of significant relevance both in biological and in clinical terms, and research in this area still has to face several complex and exciting challenges.

\section{Keywords}

hematopoietic progenitor cells, precursor cells, hematopoietic stem cell niche

\section{Open Peer Review}

Approval Status

1

2

version 1

28 Jun 2016

Faculty Reviews are review articles written by the prestigious Members of Faculty Opinions. The articles are commissioned and peer reviewed before publication to ensure that the final, published version is comprehensive and accessible. The reviewers who approved the final version are listed with their names and affiliations.

\section{Shannon McKinney-Freeman, St Jude}

Children's Research Hospital, Memphis, USA

2. Dominique Bonnet, The Francis Crick

Institute, London, UK

Any comments on the article can be found at the end of the article. 
Corresponding author: Hector Mayani (hmayaniv@prodigy.net.mx)

Competing interests: The author declares that he has no competing interests.

Grant information: The author(s) declared that no grants were involved in supporting this work.

Copyright: ( 2016 Mayani H. This is an open access article distributed under the terms of the Creative Commons Attribution License, which permits unrestricted use, distribution, and reproduction in any medium, provided the original work is properly cited.

How to cite this article: Mayani $\mathrm{H}$. The regulation of hematopoietic stem cell populations [version 1; peer review: 2 approved] F1000Research 2016, 5(F1000 Faculty Rev):1524 https://doi.org/10.12688/f1000research.8532.1

First published: 28 Jun 2016, 5(F1000 Faculty Rev):1524 https://doi.org/10.12688/f1000research.8532.1 


\section{Introduction}

The term hematopoietic stem cell (HSC) refers to an immature cell, residing in the bone marrow, which is capable of both self-renewal and differentiation into all of the different blood cell types. Evidence presented over the last few years, however, indicates that the HSC compartment comprises not just one but a number of different cell populations. This, of course, has both biological and clinical implications. Accordingly, there is great interest in elucidating the identity of each of these cell populations and defining their biological differences and similarities in molecular, immunophenotypic, and functional terms.

\section{HSCs: basic principles}

Although the concept of a primitive, immature cell common to all of the different blood cell lineages (erythrocytes, leucocytes, and platelets) was presented in the first decades of the $20^{\text {th }}$ century, it wasn't until work by James Till and Ernest McCulloch in the early 1960s that the existence of such a stem cell was demonstrated ${ }^{1,2}$. The work by Till and McCulloch, in Toronto, Canada, together with that of Metcalf and colleagues, a few years later in Melbourne, Australia, showed that the hematopoietic system could be subdivided into four separate compartments: HSCs (comprising the most immature cells, those capable of self-renewal), hematopoietic progenitor cells (HPCs; those unable to self-renew, but with a large proliferative potential and multilineage, bilineage, or monolineage differentiation capacities), precursor cells (those immature cells that can already be identified through their morphology), and mature blood cells (those present in circulation).

Although most of what we know about HSC biology comes from studies in animal models, mostly in mice, it has become evident that human HSCs follow similar biological patterns ${ }^{4,5}$. HSCs cannot be identified by morphological criteria; instead, their identification is based on both immunophenotypic analysis and functional assays ${ }^{6}$. Murine HSCs express antigens such as Sca-1, CD117, and CD150 and do not express CD48; human HSCs, on the other hand, express CD34, CD49f, CD90, and CD117 and do not express CD38 ${ }^{4,7}$. In both cases, HSCs do not express any lineage-restricted antigen, so they are referred to as lineage-negative ( $\left.\mathrm{Lin}^{-}\right)$cells ${ }^{4,7}$. It is noteworthy that within the human HSC pool a CD34-negative pop-

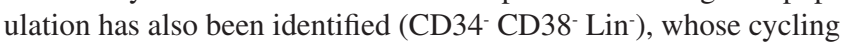
status (dormancy) suggests that it is located at the apex of the HSC compartment ${ }^{8,9}$. Apart from the expression of specific cell surface markers, HSCs can also be identified by their ability to efflux certain fluorescent dyes, such as Rhodamine-123 (Rho) and Hoechst 33342 ; thus, they are known as $\mathrm{Rho}^{- \text {-low }}$ cells or side population (SP) cells ${ }^{7}$. The latter form a characteristic cluster of events located off to the lower left side in dual wavelength fluorescenceactivated cell sorting (FACS) dot-plot profiles.

Assays to determine the number and functional integrity of HSCs include both in vivo and in vitro systems. The former consist of introducing HSCs into irradiated animals and determining the ability of such cells to repopulate the hematopoietic system of the host after several weeks post-transplant. This approach is based on the experiments described by Till and McCulloch ${ }^{1}$, although refined modifications have been introduced into the experimental system during the last few decades ${ }^{10}$. When using human HSCs, the recipient must be an immunodeficient animal (for instance, severe combined immunodeficient [SCID], non-obese diabetic [NOD]SCID, or NOD SCID Gamma [NSG] mice), so there will not be rejection mediated by the immune cells of the host ${ }^{11}$. In vitro systems, on the other hand, are based on the ability of HSCs to initiate and sustain hematopoietic cell production for several weeks in cultures containing a stromal cell layer in the presence or in the absence of exogenous cytokines ${ }^{12,13}$. It is worth noting, however, that this latter method does not necessarily prove that the cells sustaining hematopoiesis in vitro are actual HSCs; thus, to date, the in vivo repopulation assay is the only method validated to detect and measure actual HSC function.

It is of particular importance to mention that recent work from Camargo's and Rodewald's groups has presented evidence indicating that during steady-state conditions, hematopoiesis is sustained by thousands of long-lived progenitors, rather than by actual $\mathrm{HSCs}^{14,15}$. These findings suggest that HSC function may not be as critical as previously thought for unperturbed hematopoiesis; in contrast, HSC activity seems to be of great relevance during stress hematopoiesis (e.g., post-hematopoietic cell transplants).

\section{One or several HSC populations?}

Since its conception, the idea that the HSC compartment comprises a homogeneous cell population prevailed for some time; however, studies in animal (murine) models, reported over the last several years, demonstrated that some of the cells contained within the HSC pool are responsible for long-term engraftment, whereas others induce a transient, short-term engraftment ${ }^{4,6,16}$. Some groups have even suggested that, based on their engraftment potential, there are three classes of HSC: those with long-, intermediate, and short-term engraftment potential ${ }^{17}$. Thus, it is now recognized that the HSC population is heterogeneous, comprising several HSC subsets differing in their repopulation capacities and cycling properties ${ }^{18-20}$.

As expected, similar HSC populations also seem to exist in humans. Indeed, work from John Dick's laboratory in Toronto has shown that human HSCs capable of long-term engraftment express CD34, CD49f, and CD90 and, of course, lack the expression of CD38 and any lineage-restricted antigen; thus, they are defined as CD34 ${ }^{+}$ CD45RA- CD49f ${ }^{+}$CD90 ${ }^{+}$CD38- Lin cells (LT-HSCs). Loss of expression of CD49f and CD90 gives rise to transiently engrafting multipotent progenitors (MPPs [CD34+ CD45RA- CD49f CD90CD38- Lin $^{-}$cells] $)^{21}$. Based on the genomic analysis performed by the same group on these populations, 70 genes were found to be differentially expressed between HSC subsets and MPPs, whereas 500-3000 genes were differentially expressed when comparing HSCs and more mature, committed progenitors ${ }^{21}$. All these findings clearly indicate the existence of not one but several populations within the HSC compartment.

HSC heterogeneity seems to involve not only proliferative potentials, as mentioned above, but differentiation capacities as well. Work by different groups, including those of Muller-Sieburg and colleagues, Eaves and colleagues, and Suda and colleagues, has demonstrated that among murine HSCs, some clones are biased towards the production of myeloid cells ( $\alpha$-HSCs), whereas some are biased towards the production of lymphoid cells $(\gamma / \delta$-HSCs); 
furthermore, others show a balanced capacity towards the production of both myeloid and lymphoid cells ( $\beta$-HSCs $)^{17,21-24}$. It is noteworthy that the relative proportion of each one of these HSC subsets varies throughout development. For instance, lymphoiddeficient cells ( $\alpha$-HSCs) are present at very low frequencies $(<5 \%$ of all HSCs) in fetal liver, and their levels increase gradually with age, so that just before birth they constitute around $15 \%$ of all HSCs in fetal bone marrow. After birth, their levels correspond to $20 \%$ of HSCs, and in young adults their levels reach $25-30 \%$ of the HSC pool. In old mice, $\alpha$-HSCs correspond to $45 \%$ of all $\mathrm{HSCs}^{25}$. The presence of $\alpha, \beta, \gamma$, and $\delta$ HSCs in humans is less clear.

\section{How are HSCs regulated?}

HSC viability, self-renewal, proliferation, commitment, and differentiation depend on both intrinsic and extrinsic elements. The former include a variety of regulatory molecules present within the cell, whereas the latter comprise different cell types and their products, which create the microenvironment in which HSCs grow. Thus, we can say that the function of HSCs is controlled by intrinsic cell regulators, which, in turn, are modulated by external signals ${ }^{26}$. Among the intrinsic regulators of stem cell function, we find nuclear transcription factors that control gene expression (for instance, the transcription factor SCL is essential for HSC survival, self-renewal, and quiescence ${ }^{27}$ ); molecular regulators of the cell cycle, including some cyclins and cyclin-dependent kinases ${ }^{28}$ (for instance, CDK6 is absent in long-term HSCs, which keeps them quiescent even in the presence of mitogenic stimulation; in contrast, short-term HSCs express high levels of CDK6, and this results in rapid entry into the cell cycle upon mitogenic stimulation ${ }^{29}$ ); the proteins responsible for setting up symmetric and asymmetric cell divisions, such as Musashi- $2^{30}$; molecules that act as mitotic clocks that set up the number of rounds of division (HSCs express high levels of telomerase, thus the length of their telomeres does not decrease as rapidly as in more mature cells ${ }^{31}$ ); and epigenetic regulators controlling the structure and organization of DNA and chromatin ${ }^{32}$.

In postnatal life, blood cell formation takes place primarily in the bone marrow. Here, stem cells are surrounded by different cell types, including stromal (e.g., mesenchymal stromal cells [MSCs], osteoblasts, fibroblasts, adipocytes, macrophages, and endothelial cells) and accessory (e.g., lymphocytes) cells. All of these different cell types form a unique environment, known as the HSC niche, that is responsible for providing HSCs with the right conditions for their growth ${ }^{33,34}$. Interestingly, recent evidence indicates that there are, in fact, several hematopoietic niches within the marrow microenvironment, including endosteal, vascular, and perivascular niches, which exert differential effects on $\mathrm{HSCs}^{35}$. The composition of each one of these niches is different, e.g., the endosteal niche consists mainly of osteoblasts, whereas the vascular niche consists of endothelial cells. The perivascular niche, in turn, contains both MSCs and Cxcl12-abundant reticular (CAR) cells ${ }^{35}$. Current evidence indicates that most of the HSCs residing in the bone marrow (around $85 \%$ of marrow HSCs) are located within $10 \mu \mathrm{m}$ of a sinusoidal vessel ${ }^{36}$ and that cell fate is dictated mainly by elements of the perivascular niche ${ }^{35}$.

The cells that form part of the stem cell niche are able to produce and secrete a wide array of proteins - including extracellular matrix, cytokines, and chemokines - that influence stem cell behavior ${ }^{37}$. Cytokines exert their effects via specific molecules (receptors) located on the cell surface ${ }^{38}$, and they can be presented to their target cells as soluble or as membrane-bound molecules. The fact that some cytokines are presented as membrane-bound proteins implies that direct cell-to-cell interactions must take place between the cytokine-producing cell and the cytokine receptor-bearing cell. It has been suggested that the primary action of cytokines on stem cells is to prevent cell death and to promote cell division ${ }^{38}$.

\section{Controlling HSC fate}

In stem cell biology, the balance between self-renewal and differentiation is of key relevance. Cell fate decisions are associated with changes in gene expression and are controlled by the action of transcription factors ${ }^{39}$. Gene expression changes are usually accompanied (specifically preceded) by epigenetic changes in regulatory regions ${ }^{40}$. It is noteworthy, however, that the initial changes usually occur without de novo transcription and are mediated by the asymmetric distribution of cell fate determinants ${ }^{41}$.

In humans, several transcription factors have been associated with the HSC state, including ID genes, SOX8, SOX18, and NFIB. In contrast, factors such as MYC and IKZF1 have been implicated in differentiation into MPPs ${ }^{21}$. HOXB4 has also been found to be important in HSC biology, both in mice and in humans. Indeed, overexpression of such a factor in mouse HSCs induces symmetric divisions, which result in a 1000-fold expansion in HSC numbers $^{42}$. BMI1, a polycomb-group factor, increases the multilineage potential of human HSCs, as well as their replating capacity; in contrast, bmil deletion results in loss of clonal potential ${ }^{43,44}$. Other genes whose expression favors self-renewal and confers increased repopulation potential include hes 1 and $h l f^{15}$, as well as notch $^{46}$. Activation of certain genes and pathways has been implicated in the loss of HSC potential. For instance, activation of the mTOR pathway results in the loss of HSC self-renewal ${ }^{47}$; similarly, BATF activation decreases self-renewal capacity and induces lymphoid differentiation ${ }^{48}$.

Today, we know that HSC fate choices are greatly influenced and controlled by epigenetic changes. For instance, an increase in $\mathrm{H} 4 \mathrm{~K} 16 \mathrm{Ac}$ levels results in inhibition of $\mathrm{Cdc} 42$, and this, in turn, results in restoration of the $\mathrm{B}$ cell lineage output in aged $\mathrm{HSCs}^{49}$. Increased levels of $\mathrm{H} 3 \mathrm{~K} 9 \mathrm{me} 2$ mark the onset of HSC lineage commitment, whereas inhibition of G9a improves HSC maintenance ${ }^{50}$. Non-coding RNAs are also key regulators of HSC biology. MiRNA-22, for example, is a powerful inducer of HSC maintenance and self-renewal ${ }^{51}$, and very recently miRNA-126 was shown to play a key role in the self-renewal capacity and outcome of $\mathrm{HSCs}^{52}$.

\section{Implications and challenges}

Understanding the elements and mechanisms that regulate HSC populations is of significant relevance at two different levels. On the one hand, it is important in our knowledge regarding blood cell production under both normal and pathological states; thus, it helps us decipher the steps and pathways that lead to disorders such as myelodysplasia or leukemia. Indeed, particular mutations in several transcription factors have been implicated in the pathophysiology of such disorders (reviewed in 4). On the other hand, it is 
important in the development of therapeutic strategies. For instance, knowledge of the Notch pathway has led to the development of laboratory strategies for the ex vivo expansion of HSCs and HPCs from human cord blood ${ }^{53,54}$.

Research on the regulation of HSC populations still has to face several challenges. One of the most obvious is related to the development of therapeutic strategies using specific regulatory molecules and intracellular pathways as targets; for example, WNT or Notch pathways. Another one would be trying to understand aging of the HSC pool at the single cell level. In this regard, it will be of the most importance in the development of single cell RNA technologies, some of which have already been worked out, to fully understand the processes of gene regulation in HSCs from young and old individuals. Promising and exciting years are yet to come.

\section{Competing interests}

The author declares that he has no competing interests.

\section{Grant information}

The author(s) declared that no grants were involved in supporting this work.
1. Till JE, McCulloch EA: A direct measurement of the radiation sensitivity of normal mouse bone marrow cells. 1961. Radiat Res. 2012; 178(2): AV3-7. PubMed Abstract | Publisher Full Text

2. Till JE, McCulloch EA: Hemopoietic stem cell differentiation. Biochim Biophys Acta. 1980; 605(4): 431-59.

PubMed Abstract | Publisher Full Text

3. Metcalf D: The regulatory control of hemopoietic populations. Prog Clin Bio/ Res. 1990; 356: 147-54. PubMed Abstract

4. Doulatov S, Notta F, Laurenti E, et al:: Hematopoiesis: a human perspective. Cell Stem Cell. 2012; 10(2): 120-36. PubMed Abstract | Publisher Full Text

5. Szilvassy SJ: The biology of hematopoietic stem cells. Arch Med Res. 2003; 34(6): 446-60.

PubMed Abstract | Publisher Full Text

6. F Eaves CJ: Hematopoietic stem cells: concepts, definitions, and the new reality. Blood. 2015; 125(17): 2605-13.

PubMed Abstract | Publisher Full Text | Free Full Text | F1000 Recommendation

7. Wognum AW, Eaves AC, Thomas TE: Identification and isolation of hematopoietic stem cells. Arch Med Res. 2003; 34(6): 461-75. PubMed Abstract | Publisher Full Text

8. Bhatia M, Bonnet $\mathrm{D}$, Murdoch $\mathrm{B}$, et al:: A newly discovered class of human hematopoietic cells with SCID-repopulating activity. Nat Med. 1998; 4(9): 1038-45. PubMed Abstract | Publisher Full Text

9. F Anjos-Afonso F, Currie E, Palmer HG, et al:: CD34- cells at the apex of the human hematopoietic stem cell hierarchy have distinctive cellular and molecular signatures. Cell Stem Cell. 2013; 13(2): 161-74. PubMed Abstract | Publisher Full Text | F1000 Recommendation

10. Miller CL, Dykstra B, Eaves CJ: Characterization of mouse hematopoietic stem and progenitor cells. Curr Protoc Immunol. 2008; Chapter 22: Unit 22B.2. PubMed Abstract | Publisher Full Text

11. Kamel-Reid S, Dick JE: Engraftment of immune-deficient mice with human hematopoietic stem cells. Science. 1988; 242(4886): 1706-9. PubMed Abstract | Publisher Full Text

12. Sutherland $\mathrm{HJ}$, Eaves $\mathrm{CJ}$, Lansdorp PM, et al.: Differential regulation of primitive human hematopoietic cells in long-term cultures maintained on genetically engineered murine stromal cells. Blood. 1991; 78(3): 666-72. PubMed Abstract

13. Hao QL, Thiemann FT, Petersen D, et al:: Extended long-term culture reveals a highly quiescent and primitive human hematopoietic progenitor population. Blood. 1996; 88(9): 3306-13. PubMed Abstract

14. F Sun J, Ramos A, Chapman B, et al: Clonal dynamics of native haematopoiesis. Nature. 2014; 514(7522): 322-7. PubMed Abstract | Publisher Full Text | Free Full Text | F1000 Recommendation

15. $\mathrm{F}$ Busch $\mathrm{K}$, Klapproth $\mathrm{K}$, Barile $\mathrm{M}$, et al: Fundamental properties of unperturbed haematopoiesis from stem cells in vivo. Nature. 2015; 518(7540): 542-6. PubMed Abstract | Publisher Full Text | F1000 Recommendation

16. Miller PH, Knapp DJ, Eaves CJ: Heterogeneity in hematopoietic stem cell populations: implications for transplantation. Curr Opin Hematol. 2013; 20(4): $257-64$

PubMed Abstract | Publisher Full Text
17. F Ema H, Morita Y, Suda T: Heterogeneity and hierarchy of hematopoietic stem cells. Exp Hematol. 2014; 42(2): 74-82 e2. PubMed Abstract | Publisher Full Text | F1000 Recommendation

18. Foudi A, Hochedlinger K, van Buren D, et al.: Analysis of histone 2B-GFP retention reveals slowly cycling hematopoietic stem cells. Nat Biotechnol. 2009; 27(1): 84-90. PubMed Abstract | Publisher Full Text | Free Full Text

19. F Qiu J, Papatsenko D, Niu X, et al.: Divisional history and hematopoietic stem cell function during homeostasis. Stem Cell Reports. 2014; 2(4): 473-90. PubMed Abstract | Publisher Full Text | Free Full Text | F1000 Recommendation

20. F Takizawa H, Regoes RR, Boddupalli CS, et al.: Dynamic variation in cycling of hematopoietic stem cells in steady state and inflammation. J Exp Med. 2011; 208(2): 273-84.

PubMed Abstract | Publisher Full Text | Free Full Text | F1000 Recommendation

21. F Notta F, Doulatov S, Laurenti E, et al:: Isolation of single human hematopoietic stem cells capable of long-term multilineage engraftment. Science. 2011; 333(6039): 218-21.

PubMed Abstract | Publisher Full Text | F1000 Recommendation

22. Muller-Sieburg CE, Cho RH, Karlsson L, et al:: Myeloid-biased hematopoietic stem cells have extensive self-renewal capacity but generate diminished lymphoid progeny with impaired IL-7 responsiveness. Blood. 2004; 103(11): 4111-8.

PubMed Abstract | Publisher Full Text

23. Muller-Sieburg CE, Sieburg HB: The GOD of hematopoietic stem cells: a clona diversity model of the stem cell compartment. Cell Cycle. 2006; 5(4): 394-8. PubMed Abstract | Publisher Full Text | Free Full Text

24. F Dykstra B, Kent D, Bowie M, et al.: Long-term propagation of distinct hematopoietic differentiation programs in vivo. Cell Stem Cell. 2007; 1(2): 218-29.

PubMed Abstract | Publisher Full Text | F1000 Recommendation

25. $\mathrm{F}$ Babovic S, Eaves $\mathrm{CJ}$ : Hierarchical organization of fetal and adult hematopoietic stem cells. Exp Cell Res. 2014; 329(2): 185-91. PubMed Abstract | Publisher Full Text | F1000 Recommendation

26. Mayani $\mathrm{H}$ : A glance into somatic stem cell biology: basic principles, new concepts, and clinical relevance. Arch Med Res. 2003; 34(1): 3-15. PubMed Abstract | Publisher Full Text

27. F Rojas-Sutterlin S, Lecuyer E, Hoang T: Kit and Scl regulation of hematopoietic stem cells. Curr Opin Hematol. 2014; 21(4): 256-64. PubMed Abstract | Publisher Full Text | F1000 Recommendation

28. Matsumoto A, Nakayama KI: Role of key regulators of the cell cycle in maintenance of hematopoietic stem cells. Biochim Biophys Acta. 2013; 1830(2): 2335-44.

PubMed Abstract | Publisher Full Tex

29. F Laurenti E, Frelin C, Xie S, et al:: CDK6 levels regulate quiescence exit in human hematopoietic stem cells. Cell Stem Cell. 2015; 16(3): 302-13. PubMed Abstract | Publisher Full Text | Free Full Text | F1000 Recommendation

30. F Park SM, Deering RP, Lu Y, et al:: Musashi-2 controls cell fate, lineage bias, and TGF- $\beta$ signaling in HSCs. J Exp Med. 2014; 211(1): 71-87.

PubMed Abstract | Publisher Full Text | Free Full Text | F1000 Recommendation

31. Yui J, Chiu CP, Lansdorp PM: Telomerase activity in candidate stem cells from 
fetal liver and adult bone marrow. Blood. 1998; 91(9): 3255-62. PubMed Abstract

32. F Mahmud N, Petro B, Baluchamy S, et al:: Differential effects of epigenetic modifiers on the expansion and maintenance of human cord blood stem/ progenitor cells. Biol Blood Marrow Transplant. 2014; 20(4): 480-9. PubMed Abstract | Publisher Full Text | F1000 Recommendation

33. F Reagan MR, Rosen CJ: Navigating the bone marrow niche: translational insights and cancer-driven dysfunction. Nat Rev Rheumatol. 2016; 12(3): 154-68. PubMed Abstract | Publisher Full Text | F1000 Recommendation

34. F Boulais PE, Frenette PS: Making sense of hematopoietic stem cell niches. Blood. 2015; 125(17): 2621-9.

PubMed Abstract | Publisher Full Text | Free Full Text | F1000 Recommendation

35. F Morrison SJ, Scadden DT: The bone marrow niche for haematopoietic stem cells. Nature. 2014; 505(7483): 327-34.

PubMed Abstract | Publisher Full Text | Free Full Text | F1000 Recommendation

36. F Acar M, Kocherlakota KS, Murphy MM, et al:: Deep imaging of bone marrow shows non-dividing stem cells are mainly perisinusoidal. Nature. 2015; 526(7571): 126-30.

PubMed Abstract | Publisher Full Text | Free Full Text | F1000 Recommendation

37. Mayani H, Guilbert LJ, Janowska-Wieczorek A: Biology of the hemopoietic microenvironment. Eur J Haematol. 1992; 49(5): 225-33. PubMed Abstract | Publisher Full Text

38. F Metcalf D: Hematopoietic cytokines. Blood. 2008; 111(2): 485-91. PubMed Abstract | Publisher Full Text | Free Full Text | F1000 Recommendation

39. Orkin $\mathrm{SH}$, Zon LI: Hematopoiesis: an evolving paradigm for stem cell biology. Cell. 2008; 132(4): 631-44.

PubMed Abstract | Publisher Full Text | Free Full Text

40. F Bernstein BE, Mikkelsen TS, Xie X, et al:: A bivalent chromatin structure marks key developmental genes in embryonic stem cells. Cell. 2006; 125(2): 315-26.

PubMed Abstract | Publisher Full Text | F1000 Recommendation

41. Neumüller RA, Knoblich JA: Dividing cellular asymmetry: asymmetric cell division and its implications for stem cells and cancer. Genes Dev. 2009; 23(23): 2675-99.

PubMed Abstract | Publisher Full Text | Free Full Text

42. Antonchuk J, Sauvageau G, Humphries RK: HOXB4-induced expansion of adult hematopoietic stem cells ex vivo. Cell. 2002; 109(1): 39-45. PubMed Abstract | Publisher Full Tex

43. Rizo A, Dontje B, Vellenga E, et al:: Long-term maintenance of human hematopoietic stem/progenitor cells by expression of BMI1. Blood. 2008; 111(5): $2621-30$

PubMed Abstract | Publisher Full Tex
44. Rizo A, Olthof S, Han L, et al.: Repression of BMI1 in normal and leukemic human $\mathrm{CD}^{+} 4^{+}$cells impairs self-renewal and induces apoptosis. Blood. 2009; 114(8): 1498-505

PubMed Abstract | Publisher Full Text

45. Shojaei F, Trowbridge J, Gallacher L, et al:: Hierarchical and ontogenic positions serve to define the molecular basis of human hematopoietic stem cell behavior. Dev Cell. 2005; 8(5): 651-63. PubMed Abstract | Publisher Full Text

46. Varnum-Finney B, Xu L, Brashem-Stein C, et al:: Pluripotent, cytokine-dependent, hematopoietic stem cells are immortalized by constitutive Notch1 signaling. Nat Med. 2000; 6(11): 1278-81.

PubMed Abstract | Publisher Full Tex

47. F Huang J, Nguyen-McCarty M, Hexner EO, et al:: Maintenance of hematopoietic stem cells through regulation of Wnt and mTOR pathways. Nat Med. 2012; 18(12): 1778-85.

PubMed Abstract | Publisher Full Text | Free Full Text | F1000 Recommendation

48. F Wang J, Sun Q, Morita Y, et al.: A differentiation checkpoint limits hematopoietic stem cell self-renewal in response to DNA damage. Cell. 2012; 148(5): 1001-14

PubMed Abstract | Publisher Full Text | F1000 Recommendation

49. F Florian MC, Dörr K, Niebel A, et al: Cdc42 activity regulates hematopoietic stem cell aging and rejuvenation. Cell Stem Cell. 2012; 10(5): 520-30. PubMed Abstract | Publisher Full Text | Free Full Text | F1000 Recommendation

50. Chen X, Skutt-Kakaria K, Davison J, et al.: G9a/GLP-dependent histone H3K9me2 patterning during human hematopoietic stem cell lineage commitment. Genes Dev. 2012; 26(22): 2499-511.

PubMed Abstract | Publisher Full Text | Free Full Text

51. F Song SJ, Ito $\mathrm{K}, \mathrm{Ala} \mathrm{U}$, et al:: The oncogenic microRNA miR-22 targets the TET2 tumor suppressor to promote hematopoietic stem cell self-renewal and transformation. Cell Stem Cell. 2013; 13(1): 87-101.

PublMed Abstract | Publisher Full Text | Free Full Text | F1000 Recommendation

52. F Lechman ER, Gentner B, Ng SW, et al: miR-126 Regulates Distinct SelfRenewal Outcomes in Normal and Malignant Hematopoietic Stem Cells. Cancer Cell. 2016; 29(2): 214-28.

PubMed Abstract | Publisher FullText | Free Full Text | F1000 Recommendation

53. F Delaney C, Heimfeld S, Brashem-Stein C, et al:: Notch-mediated expansion of human cord blood progenitor cells capable of rapid myeloid reconstitution. Nat Med. 2010; 16(2): 232-6.

PubMed Abstract | Publisher Full Text | Free Full Text | F1000 Recommendation

54. Mayani $\mathrm{H}$ : Notch signaling: from stem cell expansion to improving cord blood transplantation. Expert Rev Hematol. 2010; 3(4): 401-4.

PubMed Abstract | Publisher Full Text 


\section{Open Peer Review}

\section{Current Peer Review Status:}

\section{Editorial Note on the Review Process}

Faculty Reviews are review articles written by the prestigious Members of Faculty Opinions. The articles are commissioned and peer reviewed before publication to ensure that the final, published version is comprehensive and accessible. The reviewers who approved the final version are listed with their names and affiliations.

\section{The reviewers who approved this article are:}

\section{Version 1}

\section{Dominique Bonnet}

Haematopoietic Stem Cell Laboratory, The Francis Crick Institute, London, UK

Competing Interests: No competing interests were disclosed.

\section{Shannon McKinney-Freeman}

Department of Hematology, St Jude Children's Research Hospital, Memphis, TN, 38105, USA

Competing Interests: No competing interests were disclosed.

The benefits of publishing with F1000Research:

- Your article is published within days, with no editorial bias

- You can publish traditional articles, null/negative results, case reports, data notes and more

- The peer review process is transparent and collaborative

- Your article is indexed in PubMed after passing peer review

- Dedicated customer support at every stage

For pre-submission enquiries, contact research@f1000.com 